\title{
Dictynna
}

Dictynna

Revue de poétique latine

16 | 2019

Varia

\section{The Shade of Orpheus : Ambiguity and the Poetics of Vmbra in Metamorphoses 10}

\section{Celia Campbell}

\section{Q OpenEdition \\ 1 Journals}

\section{Electronic version}

URL: http://journals.openedition.org/dictynna/1814

DOI: 10.4000/dictynna.1814

ISSN: 1765-3142

\section{Electronic reference}

Celia Campbell, "The Shade of Orpheus : Ambiguity and the Poetics of Vmbra in Metamorphoses 10 », Dictynna [Online], 16 | 2019, Online since 19 December 2019, connection on 11 September 2020. URL : http://journals.openedition.org/dictynna/1814; DOI : https://doi.org/10.4000/dictynna.1814

This text was automatically generated on 11 September 2020.

\section{(c) (i) (9)}

Les contenus des la revue Dictynna sont mis à disposition selon les termes de la Licence Creative Commons Attribution - Pas d'Utilisation Commerciale - Pas de Modification 4.0 International. 


\title{
The Shade of Orpheus : Ambiguity and the Poetics of Vmbra in Metamorphoses 10
}

\author{
Celia Campbell
}

1 In Book 10, the narrative reins of Ovid's Metamorphoses are ceded to the constructed whims of a notable internal poet-singer: the mythical bard Orpheus. In this way, Orpheus follows in the footsteps of his mother, the Muse Calliope, who is granted a large portion of narrative space within Book 5, similarly occupying a pentadic structural point within the epic. These acts of internal narration are, however, not just linked structurally, nor by the loosely imposed idea of a continuity established through generational descent, but are affiliated through the circumstance of their staging. The communication of Calliope's narrative is predicated on a poetic covenant familiarised by the pastoral tradition : the Muse asks her audience, the goddess Minerva, if she has sufficient leisure (otia, Met. 5.333) to listen to the song, to which the goddess replies affirmatively, and makes herself at home as a listener within the landscape (Pallas ait nemorisque leui consedit in umbra, 'Pallas replied and settled herself within the lightly shaded grove', 5.336). Her relaxed position in the shade (umbra) reveals her readiness to receive the song of the Muse. ${ }^{1}$ The song of Orpheus, too, is predicated upon the existence of shade, but the shade that provides cover for Orpheus' song is fraught with a host of associations that transcend the positive overtones found in simple bucolic need: pastoral singers seek the available cover of shade, but Orpheus is no typical bucolic herdsman passing the time with pleasant intervals of song. Rather, the shade that he furnishes for himself with the grove he musically summons is an atmosphere of deep ambiguity. The grove of Orpheus provides the focal point of this discussion, which seeks to reorient the grove's conceptualisation and interpretation as a poetic landscape, on two levels of significance: what it means to Orpheus, the internal narrator, and to Ovid, the epic poet. I suggest that the grove summoned is most productively understood as an atmospheric doublet of the Underworld, a landscape of liminality conjured by Orpheus in an effort to reproduce and regain imaginative access to his lost wife Eurydice. The creation of the grove as an earthly evocation of the 
Underworld is both made permissible and activated by the double meaning of umbra, denoting the shade of a tree or shade of the dead. While the construction of the grove under this atmospheric authority makes a landscape designed to accommodate and reflect the song Orpheus sings within its confines, the tree catalogue also represents Ovid's metamorphosing of the epic topos of the tree catalogue : on this wider narrative level, Orpheus' grove further symbolically functions as a poetic funeral pyre. The tree catalogue therefore bears internal and external resonance for its conceptual recollection of death and the underworld, implicating both Orpheus and Ovid in a joint enterprise to shape the identity of this poetic landscape as not a simple locus amoenus, but a space of fundamental ambiguity and liminality.

\section{Singing to the Shade : Orpheus' Grove and the Underworld}

2 After Orpheus' journey to the Underworld, he returns unwillingly to his Thracian homeland, thwarted of his heart's desire (despite a successful song). The level, verdant plain where he resumes his defining activity as a bard and prepares to sing anew lacks a cover of shade, and so he strums his lyre and charms the landscape into providing this cover. Not just any shade arrives at his musical behest, but a grove of twenty-seven trees. His need may appear purely pastoral, but the shade that arrives is anything but :

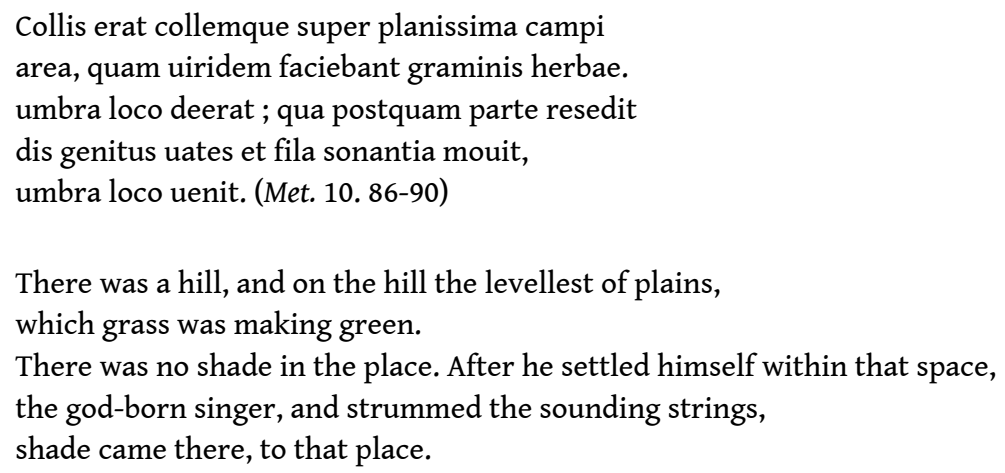

3 The catalogue that follows is populated by impressive detail-twenty-seven trees in total, twenty-six within the space proper of the catalogue, whilst the cypress stands as the twenty-seventh, included in the extended aetiological tale of Cyparissus. Despite the remarkability of the grove's arboreal cover-a surfeit, really, of pastoral shade-the catalogue has largely escaped the detailed attention of Ovid's readers and commentators. ${ }^{2}$ The shade that Orpheus summons in which to stage his return to song is twice denoted by umbra (Met. 10. 88, 90); the trees not only form the desired environment for the production of song, but also comprise the immediate audience of Orpheus' song, a song of love and loss through which his own experience is filtered. While the lack of shade is one thing Orpheus can redress with his enchanting powers of song, the loss of his wife is not so easily remedied. The well-recognised dual meaning of umbra circumstantially links this new song of Orpheus with the song he performs in the Underworld in his attempt to regain Eurydice, a song which also had an audience of shades (10.17-39). ${ }^{3}$ The relationship between the two meanings of the word and their appearances at these critical junctures in the book has either been disavowed ${ }^{4}$ or restricted to the act of alluding specifically to the umbra of Eurydice. ${ }^{5}$ Eurydice, in remaining an umbra despite the efforts of Orpheus, certainly facilitates an evocation of 
this semantic overlap, but her existence as a shade is not the only component that allows for this duality of meaning to be activated. Instead, the dual meaning of umbra should be allowed to rest on the level of generality. This allowance creates an atmospheric equivocation between these two arenas of Orphic song, the grove and the Underworld. The power Orpheus displays over the trees in arranging them about himself has already been seen at work over the shades in Tartarus: the shades themselves weep, while Tantalus ignores the fleeing water, the wheel of Ixion halts, the eagles no longer pluck at the liver of Tityus, the urns of the Danaids lie vacant, and Sisyphus perches on his rock; even the Furies weep for the first time (10. 40-46). These various personages are signalling features of the Stygian landscape, as much as its own 'natural' features of marshes and swamps, patches of misty darkness, rivers coiling through dark valleys. The terrain of the Underworld is known by these characters and demarcated by the environments that comprise their personal vignettes of punishment: Virgil, Propertius, and Tibullus all integrate such characters in giving shape to their poetic Underworlds. ${ }^{6}$ Orpheus' control over the shades of the Underworld may be regarded as a type of control over the Stygian landscape itself, which is subsequently transmuted into his power over the Thracian landscape and the gathering of the appropriate conditions for song. An atmospheric connection is forged through the similar 'shady' audiences of his songs, which fashions the grove as a new Underworld.

4 The phrases communicating the initial lack of shade and its Orphic remedy are echoing and responsive : umbra loco deerat ('shade was lacking in the space', 10.88) is answered by umbra loco uenit ('shade came to the space', 10. 90), as Orpheus strums his lyre. The introductory structure of the catalogue reinforces this play between presence and absence: the presence of the trees that heed Orpheus' musical call is initially communicated by double negatives, non Chaonis abfuit arbor ('nor was the Chaonian tree absent', 10. 90). This construction prioritises absence over presence, as the lack of shade is remedied by a list of trees that are, to paraphrase loosely, not not there. ${ }^{7}$ Awareness of such a line between absence and presence is also immanent in the idea of an umbra; the shade of the departed is simultaneously there and not there, something seen but ungraspable. ${ }^{8}$ Lending the catalogue this shape makes the shade of the trees thematically contiguous with the shades of the Underworld, promoting a greater sense of environmental continuity between the locales of Orpheus' two songs.

5 Ovid also communicates a sense of world-building within the formation of the grove by a subtle feint towards the realm of cosmogony with the opening tree, the Chaonis arbor (10. 90). Ostensibly, the Chaonis arbor opens the catalogue because of its connection to Jupiter, for it neatly mirrors the opening of Orpheus' song ('ab Ioue, Musa parens, (cedunt Iouis omnia regno),/carmina nostra moue', ' from Jove, mother Muse, for all things yield to the power of Jove, stir my song', 10.148-149), and initiates the many parallels between the creation of the grove and the creation of the song it becomes home to. However, the embedded chaos found in Chaonis also hints at the act of cosmogony, gesturing towards the space of world-beginnings. ${ }^{9}$ During his descent, Orpheus begs in the name of three places for Eurydice's release, including per Chaos hoc ingens (10.30); appearing a mere sixty lines before the appearance of the Chaonis arbor, this makes an activation of the verbal play both more deliberate and suggestive. In this usage, Chaos is employed as a designation for the void of the Underworld, which likewise lends another valence to 
discovering chaos in Chaonis. ${ }^{10}$ This first tree therefore delineates the space of the grove as distinct and other, and one with a link to the Underworld.

\section{Otherworldly Precedents : Ovidian Landscapes of Liminality}

6 The grove of Orpheus is not the only landscape within the Metamorphoses to carry such imbuements of otherworldly places. Two of these landscapes merit recognition here, along with the attendant experiences of their environments : Narcissus' pool and the wood surrounding Pergus, the site of Proserpina's abduction. As stated, on a practical level, one hardly imagines twenty-seven trees necessary for the provision of the type of protective cover a singing performance generally demands. The grove represents much more than cursory shelter from the sun. Blocking the rays of the sun is a specifically detailed descriptive characteristic of the forest surrounding Narcissus' pool :

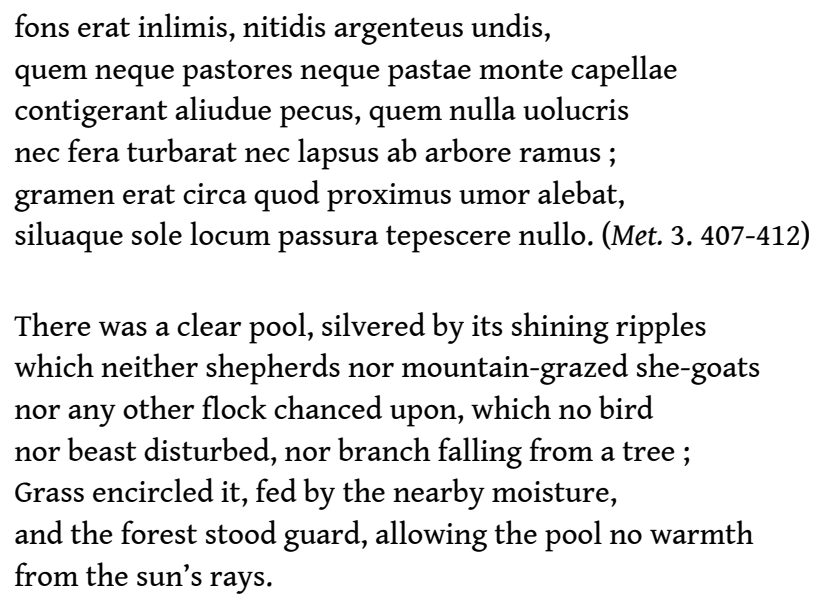

7 The chilly perfection of Narcissus' pool, where no sun allowed to penetrate and warm its waters, lends a distinct air of the Underworld's stasis. Its stillness is otherworldly, disturbed by neither man, beast, nor even nature itself. The lack of birds (nulla uolucris... turbarat), given that bird-song is a stereotypical feature of the locus amoenus, could also indicate awareness of the Greek derivation of Avernus from óopvic. ${ }^{11}$ Beside and within this otherworldly pool, Narcissus' continual, frustrated attempts to embrace his reflection also echo the efforts made to try and embrace the shades of loved ones. ${ }^{12} \mathrm{His}$ reflection is itself, tellingly, called an imaginis umbra ('shadow of a likeness', 3. 434). ${ }^{13}$ Although Tarrant treats line 3. 417 as an interpolation in his edition of the Metamorphoses, Hardie not only preserves the line, but reads the alternate manuscript tradition of umbra in place of unda (spem sine corpore amat, corpus putat esse quod umbra est, 'he loves a disembodied hope, giving a form to what is only shadow'), as he traces the Lucretian influence and inspiration within Ovid's tale of Narcissus. He identifies Narcissus' behavioural interactions with his 'beloved' as rooted within Lucretius' description of the imagistic experience of seeing into a sort of Underworld when gazing into a puddle of water (Lucr. DRN 4. 416-419). ${ }^{14}$ Narcissus and Orpheus are figures further united by experiencing versions of paraclausithyra staged by the natural world, ${ }^{15}$ as water acts as the dividing force for Narcissus and his beloved reflection, whilst Orpheus is barred from re-entry into the Underworld (and therefore, from access to Eurydice) by the Styx (10.72-75). Each lover is so preoccupied as to neglect basic human need for food and drink $(3.437-438 ; 10.73-75)$, and their loves yet endure in the dark 
wastes of the Underworld : Narcissus, as a shade, still gazes at his reflection in the Styx (tum quoque se, postquam est inferna sede receptus,/in Stygia spectabat aqua, 'even then, after he was welcomed to the infernal realm, he yet gazed at himself in a Stygian mirror', 3. 504-505), whilst Orpheus professes that he shall stay there if his request is denied ('quod si fata negant ueniam pro coniuge, certum est/ nolle redire mihi; leto gaudete duorum,' 'but if the fates deny me mercy on my wife's behalf, there is one certainty: I do not wish to make my own return. Rejoice in a twinned death', 10.38-39). Although Orpheus is rebuffed in his attempts to cross the river again in the wake of Eurydice's second loss, he nevertheless symbolically returns to the Underworld through his creation of the dark grove, and sings again, as he once did in order to regain her. ${ }^{16}$ Narcissus, too, shares in the experience of acknowledging and manipulating trees as an audience for poetic expressions of loss, desire and longing. In an isolated moment, tearing his gaze from his reflection, Narcissus calls upon the surrounding trees as witnesses :

paulumque leuatus,

ad circumstantes tendens sua bracchia siluas

'ecquis, io siluae, crudelius' inquit 'amauit?

scitis enim et multis latebra opportuna fuistis.' (Met. 3. 440-443)

Barely tearing himself away,

stretching out his arms to the witnessing wood

he cries, 'is there anyone who has loved more cruelly,

trees? You should know ; you have lent yourself as secret lairs to many a lover.'

8 Narcissus' supplicating gesture as he bewails the cruelty of his love (tendens sua bracchia) is gesturally echoed by Orpheus' attempt to embrace the shade of Eurydice (bracchiaque intendens, 10.58), ${ }^{17}$ but the idea of trees as witnesses consciously attuned to love takes root more concretely in Orpheus' grove, where many of the trees present are in fact subjects of the Metamorphoses now veiled by their transformations: Daphne is present as the innuba laurus (10.92) the first addition to the natural world in Book 1; the sisters of Phaethon from Book 2 form the nemus Heliadum (10. 91); Baucis, whose story is narrated in Book 8, is in attendance as the tilia (10.91), while Dryope and Lotos are represented by the lotus (10.96), a transformation told in Book 9. They are physical witnesses to Orpheus' song as its own part of the Metamorphoses, but also literary witnesses, which further transforms Orpheus' grove into not just a literal grove, but symbolically rendered as a textual grove. ${ }^{18}$ The grove of Orpheus sequesters narratives from the wider narrative frame of the Metamorphoses, culling an audience from its volumes in a fashion mimetic of his own narrative role within its pages; this is repeated within his song in the inset narration of Venus to Adonis of Atalanta and Hippomenes (10.560-707), thereby creating an instance of narrative ring composition that mimics the circular arrangement of the grove around the singer. Ovid does not let his readers forget that although Orpheus is the internal manipulator of the landscape, it is nevertheless Ovid's own construct of literary shade that Orpheus shrouds himself with.

9 Narcissus and his mode of interaction with his physical surroundings therefore find a number of resonances within Orpheus' tale, not least in the ways in which their respective landscapes are marked by atmospheric connectivity to a different realm. The woods surrounding Pergus also deserve mention (albeit more briefly) for the way they likewise imaginatively conjure the presence of the Underworld. In a familiar visual 
dynamic, the fringe of trees surrounding the lake similarly forbids the passage of sunlight: silua coronat aquas cingens latus omne suisque/ frondibus ut uelo Phoebeos summouet ictus ('A wood crowns the waters, encircling it from all sides with bowing branches, so keeping out the rays of the sun with its leafy veil', 5. 388-389). This landscape configuration neatly anticipates Proserpina's abduction to the Underworld, a place sunlight cannot penetrate. ${ }^{19}$ The shady darkness that characterizes this natural environment of her ensconcing, like the dead calm of Narcissus' reflecting pool, symbolically prefigures her displacement to the Underworld, and also visually projects in compressed, naturalistic iconography, her new role: the darkness of the foliage takes the form of a crown (coronat) and veil (uelo), painting her as the royal matrona of Pluto (cf. 5. 506-508, where Arethusa identifies her as a new regina and matrona). ${ }^{20}$ The fates of Narcissus and Proserpina are written into and projected by the landscape, and, as such, they provide apt imaginative frameworks with which to consider Orpheus' grove. However, the grove of Orpheus reverses these acts of symbolic foreshadowing enacted by the physical landscape; instead, he is the active agent in creating an atmosphere designed to return him to a previous time and place. The grove is an environment masquerading as an emotional time-capsule: the very creation of the grove is an act of looking back, an attempt to return to the environs of the Underworld where his song was successful, but he himself was not.

\section{Casting Shadows : the Legacy of Virgilian Umbrae}

10 Now that the overall descriptive context has been established for Ovid consciously trading upon the range of meaning of umbra, and two contextually evocative Ovidian landscapes discussed as precedents for the generative dynamic behind Orpheus' grove, the subtleties of this interplay with umbra warrant more detailed attention. The grove as a purposefully constructed atmospheric doublet of the Underworld inherently makes it a space of complicated liminality, and ambiguous in a way that the stereotypical epic grove or locus amoenus is emphatically not. The ambiguity of this grove is also determined by and reliant upon the ambiguity in umbra's meaning; it is the literary consciousness of this semantic overlap and its potential for exploitation that can now be addressed. Primarily, we shall see how the Ovidian manipulation of umbra and this awakening of ambiguity traffics in the legacy of the progressive exploration of umbra Virgil makes across his poetic oeuvre.

11 Shade is, of course, a defining symbol of the Eclogues. The image of shade provides a crystallising instance of ring composition both within the first Eclogue and the collection as a whole: the repose of Tityrus, lentus in umbra, is recalled in his offer of hospitality to Meliboeus, against the backdrop of evening's spreading shadows (et iam summa procul uillarum culmina fumant/ maioresque cadunt altis de montibus umbrae, 'and already the tallest rooftops of the faraway villas are smoking, and growing shadows fall from the mountain heights', Ecl. 1. 82-83). These evening shadows, neither explicitly ominous, nor the pastoral protective cover from the midday sun, are transformed into the final image of shade that closes the Eclogues, where the bucolic world draws homewards in response to this dangerous, closural shade :

surgamus : solet esse grauis cantantibus umbra, iuniperi grauis umbra; nocent et frugibus umbrae.

ite domum saturae, uenit Hesperus, ite capellae. (Ecl. 10.75-77) 
Let us arise : shade can be harmful to those singing,

the oppressive shade of the juniper ; the shadows impede growth.

Go home, goats, grazed to satisfaction ; the evening star arrives.

\section{finality that begins to hint at umbra's multiplicity of meanings-to resemble shade as a} monument to the finality of death. Gallus, the subject of lament throughout the final Eclogue, is perishing from love (indigno...amore peribat, 'perishing from an unworthy love', Ecl. 10.10), loosely assuming the role of the dying Daphnis from Theocritus' first Idyll. Even though the figure of the dying Gallus in Eclogue 10 is a poetic construction, a combination of literary borrowing and historical reality that describes a metaphorical, rather than real, death, there is yet a way that umbra can be interpreted within the framework of death as the poem presents it. This use of umbra within the framework of metaphorical death also confines its duality of meaning to a significance of greater subtlety. In the embedded lament of Gallus, he associates himself, his poetry, and love with trees, as they become the communicative medium for his love : he shall carve his love (amores) or love poetry (Amores) on trees, consigning his love and poetry to the hopes of memorialising, arboreal growth (Ecl. 10. 52-54). ${ }^{21}$ Gallus' love, finding imagistic expression on trees, is transformed into the image of Virgil's own love for Gallus, a love that likewise grows as trees (Gallo, cuius amor tantum crescit in horas/ quantum uere nouo uiridis se subicit alnus, 'for Gallus, love of whom grows as much by the hour as the alder in early spring submits itself to its own greening', Ecl. 10. 73-74). ${ }^{22}$ The trees bearing Gallus' poetry (and prefiguring himself eventually becoming an umbra, perishing from love in the sustained imagining of this poetic scenario) are the trees whose influential shade Virgil needs to escape, ${ }^{23}$ a process he begins with supplanting the Gallan trees with his own image of the alder, which then cedes to the final darkness of shade that must be avoided. Gallus' metaphorical 'death' yet speaks to a moment where Gallus will become a shade, as he leaves behind a poetic monument in the form of shade, in his inscribed trees. The undertones of death are here delicately veiled, as befits the ultimately figurative notion of Gallus' fatal lovesickness, infiltrating the scene contextually in the nexus of arboreal imagery that visualises love and elegy, the genre of both love and loss. A direct allusion to the alternate meaning of umbra as a ghost would here irrevocably and irreparably overpower the positive associations for pastoral, tainting the host of symbolic meanings accrued within the meticulously curated space of the Eclogues ; the associations are too dangerous for explicit evocation, but not for subtle implication, opportunely evoked by the 'dying' Gallus and his elegiac arboreal monument.

13 Gallus and the closing image of the tenth Eclogue begin to hint at the range of significance umbra holds, but there is no explicit exploitation of the full effect the overlap in meaning can furnish. The faint trace of this potential borne at the end of the Eclogues, however, accumulates associative meaning in the final book of the Georgics, in the Orpheus-Eurydice epyllion, which gives Ovid a restrained model for his own treatment of the myth in the Metamorphoses, where he does make a direct link between the shades of the Underworld and the shade(s) of the grove. Virgil embeds fragments and images of atmospheric continuity between Orpheus' experience in the Underworld and his return to Thrace that gain more suggestive depth when the filter of umbra's dual meaning is imposed. Virgil first introduces the shades of the Underworld in a reworked Homeric simile. They flock, birdlike, to the sounds of Orpheus' song : 
at cantu commotae Erebi de sedibus imis

umbrae ibant tenues simulacraque luce carentum, quam multa in foliis auium se milia condunt,

Vesper ubi aut hibernus agit de montibus imber. (Georg. 4.471-474)

And conjured by song, from the deepest roots of Erebus the shades gather, wisps, and the forms of those deprived of life's light as many as the thousands of birds that hide away in the shelter of foliage when the evening star comes, or a winter rain descends from the mountains.

The shades gather in the manner of birds that themselves hide away amidst the shade. Another way to translate condunt could be to 'bury', effectively seeing the birds metaphorically inter or entomb themselves amidst the shade, lending a further layer of the implication of death through the verb's multivalence. ${ }^{24}$ The wintriness of the simile (hibernus) anticipates the strong sense of gelid sterility expressed in the Thracian landscape Orpheus returns to, scorning love (solus Hyperboreas glacies Tanaimque niualem/ aruaque Riphaeis numquam uiduata pruinis/ lustrabat..., 'alone he wanders the icy Hyperborean northlands and the snowy Don and the fields along the Riphaean ridge, never without the sheen of frost', Georg. 4. 517-519), but it is the comparison of shades to birds that is contextually reactivated in the simile comparing the lovelorn Orpheus to a mourning nightingale :

qualis populea maerens philomela sub umbra

amissos queritur fetus, quos durus arator

obseruans nido implumis detraxit ; at illa

flet noctem, ramoque sedens miserabile carmen

integrat, et maestis late loca questibus implet. (Georg. 4.511-515)

Just as the nightingale mourning under the poplar shade laments her missing nestlings, which the pitiless farmer watchful, dragged from the nest, without the down of feathers;

and so she grieves by night, sitting on the branch, making her

mournful song anew, and she fills the spaces far and wide with her sad cries.

The nightingale, grieving under the shade (sub umbra) and at night (flet noctem), functions as a textual hinge, looking back to the simile of shades as birds within the darkness of the Underworld, as she occupies an environment that is also determined by the presence of umbra. ${ }^{25}$ With these sets of similes, Virgil builds a notion of a collective shared environment within this simile-space, one that is strengthened in tonal evocations of darkness and mourning by awareness of the double meaning of umbra. The lines in meaning are blurred within this shared conceptual space of shades as birds, and Orpheus as a bird, mourning under the poplar.

The Orpheus-Eurydice epyllion itself casts a long shadow of influence, first of all upon Virgil himself. In refashioning his own mythical treatment to fit the contours of the encounter between Creusa and Aeneas in Aeneid 2, Virgil loosens such measures of restraint in capitalising upon this overlap in meaning $:^{26}$

ausus quin etiam uoces iactare per umbram

impleui clamore uias, maestusque Creusam

nequiquam ingeminans iterumque iterumque uocaui.

quaerenti et tectis urbis sine fine ruenti

infelix simulacrum atque ipsius umbra Creusae

uisa mihi ante oculos et nota maior imago. (Aen. 2.768-773) 
Even yet, venturing to cast my voice through the shadow

I filled the streets with my cry, and sadly, I called 'Creusa'

again and again, redoubling my efforts in vain.

And the unlucky image, the very ghost, of Creusa herself

appeared before my eyes, that had been seeking her

in the ceaseless ruin of the city ; this vision of her was larger than life.

Virgil uses umbra twice within the space of five lines, first to describe the darkness of the Hell of falling Troy, and secondly, to describe the spirit of the vanished Creusa. The closeness of the repetition forcibly associates the two meanings, encouraged by the vertical juxtaposition of the line endings umbram and Creusam (2.768-769). Aeneas is recast as the nightingale-Orpheus from Georgics 4, echoing her song of mourning (et maestis late loca questibus implet, 'she fills the spaces far and wide with sad cries', Georg. 4. 515) with his 'song' of searching. ${ }^{27}$ The night-time shadows, an Underworld redux, anticipate the shade of Creusa, materialising from their midst, overtly signalling awareness of a blend of significance.

Before moving on to the further literary legacy of Virgil's Orpheus and related manipulated usages of umbra, it is worth recalling Gowers' summarising words on Virgilian shade, which reinforces just how critical the idea of shade is to the poet, and the cumulative momentousness of its significance to his works, both structurally and symbolically. In discussing the Corycian senex from Georgics 4, she takes as her point of departure the poet's ending of this enclosed narrative with shade, coming on the heels of his description of the landscape's seasonal acceleration : "as for the very last word of the description, umbras ('shade', 146), this corresponds to the last word of the first Eclogue (umbrae, 1.83), the last word of the penultimate line of the last Eclogue (umbrae, 10.76), and the last word of the Aeneid (umbras, 12.952), which links this miniature progress through the seasons to Virgil's other sombre poetic endings, past and future, and the patterned end of a poetic career : death, or basking in the shadow of a tree." ${ }^{28}$ It is a consciousness of these endings, and how their different meanings yet imbue each other with a referential awareness and significance, that further contribute to a sense of powerful ambiguity able to be harnessed in developing further the poetic capabilities of umbra in post-Virgilian verse.

\section{Lighter Shades : Orpheus and the Inherited Poetics of Umbra}

19 The Virgilian Orpheus also provides the initial thread in an intricate latticework of intertextuality that further informs how Ovid characterises his Orpheus, as regards both song and landscape. One of the receptive strands of Virgilian influence is found in Horatian lyric, most powerfully in a circumstance that also brings together the ideas of death and trees: the curse-ode Horace directs at the tree that nearly kills him, which ends in a series of images as imaginatively experienced in the poet's 'catabasis.' The fanciful vignette of the enchanting powers of song displayed by Alcaeus (contrasted with the powers of Sappho) is patterned after Orpheus. ${ }^{29}$ The audience for these song offerings are the shades (umbrae):

quam paene furvae regna Proserpinae

et iudicantem vidimus Aeacum

sedesque discretas piorum et

Aeoliis fidibus querentem 
Sappho puellis de popularibus, et te sonantem plenius aureo, Alcaee, plectro dura navis, dura fugae mala, dura belli. utrumque sacro digna silentio mirantur umbrae dicere, sed magis pugnas et exactos tyrannos densum umeris bibit aure volgus. (Hor. Carm. 2.13.21-32)

Just barely did I escape seeing the dusky kingdom of Proserpina and the adjudications of Aeacus, and the seats sequestered for the loyal and Sappho, lamenting in Aeolian strains girls of her native lands and you, Alcaeus, sounding off in fuller fashion with your golden plectrum, about the hardships of life at sea, the harsh realities of exile, the weights of war. The shades marvel at each proclaiming things worthy of silence's sacrament, but the throng, jostling shoulder to shoulder, drinks in with more eager ear battlesongs and of tyrants run out.

Alcaeus wins the popular vote: his songs, thrice characterised as dura, capture the attention of the shades more successfully than the elegiac lamenting of Sappho (Aeoliis fidibus querentem/ Sappho puellis de popularibus). Alcaeus as the Orpheus-figure is noteworthy here, for other textual resonances otherwise align Orpheus more closely with Sappho. In the case of Ovid (or his imitators), this is especially notable in Heroides $15,^{30}$ which details Sappho relinquishing lyric for elegy out of love for Phaon; she characterises her new genre as 'tearful', elegia flebile carmen (ES 7). This pointed designation for elegy powerfully links Sappho to the Orpheus of Metamorphoses 10/11:

caput, Hebre, lyramque

excipis, et (mirum !) medio dum labitur amne,

flebile nescioquid queritur lyra, flebile lingua

murmurat exanimis, respondent flebile ripae. (Met. 11.50-53)

You welcomed his head and lyre, Hebrus,

and while it streamed down the middle of the eddies (the marvel !)

the lyre lamented something tearful, the lifeless tongue murmured

tearfully, and the banks echoed, tearful in turn.

Sappho and Orpheus are also biographically linked through the circumstances of their love: Sappho, famed for her poems addressed to female loves, now writes in a new genre expressing her passion for a male lover, while Orpheus too has had the objects of his desire transferred from female to male, and must find measures to suit. Sappho furthermore compares herself to a nightingale, which intertextually binds her experience of love to the Orpheus of Georgics 4 :

quin etiam rami positis lugere uidentur

frondibus, et nullae dulce queruntur aues.

sola uirum non ulta pie maestissima mater

concinit Ismarium Daulias ales Ityn.

ales Ityn, Sappho desertos cantant amores.

hactenus ; ut media cetera nocte silent. (ES 151-156)

And even the branches appear to grieve with falling

leaves, and no birds sing their sweet complaints.

Only the most mournful mother, unlawful avenger of her husband,

sings, the Daulian bird, of Thracian Itys. 
Sappho may mourn like the nightingale-that is to say, like the Virgilian Orpheus-but the specification of Daulias also implicates Catullus within this illustration of querulous lament. ${ }^{31}$ Catullus mourns his lost brother as the nightingale sings under the cover of shade in very much an instance of self-conscious trading upon umbra's dual meaning :

at certe semper amabo,

semper maesta tua carmina morte canam,

qualia sub densis ramorum concinit umbris

Daulias, absumpti fata gemens Ityli.- (Catull. 65.11-14)

But of course I will always love you

always I will sing songs saddened by your death

just as the Daulian bird sings under the close shade of branches

bewailing the fate of Itys, stolen away.

Catullus' use of umbra is especially marked by virtue of its position as a departure from his poetic model, a passage in the Odyssey where the myth is briefly presented in a portrait of Penelope mourning as the nightingale, 'sitting amongst the thick leaves of

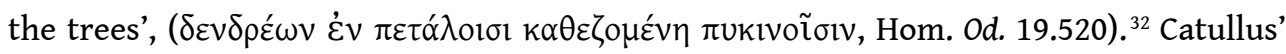
densis ramorum...umbris hearkens back to this Homeric description, but substitutes umbris for $\pi \varepsilon \tau \tau^{\prime} \lambda \operatorname{lol\sigma l}^{33}$ This poem also marks the juncture at which the Catullan collection shifts towards elegy, which, along with the presence of the Muses and vocabulary of clear generic reference, has led to speculation about its positioning as being programmatic for an elegiac volume. ${ }^{34}$ Sappho, in penning her letter to Phaon in this newly assumed elegiac form, therefore also seems inspired not only by Catullan imagery, but by this structural relevance of this Catullan poem within the collection; she also draws upon an image of the 'Daulian' bird to effect awareness of a generic shift. ${ }^{35}$ Sappho, having taken up the mantle of the elegiac Catullus in writing to Phaon, abandoning lyric, also seems to acknowledge this same ode of Horace (2.13) and the privileging of Alcaeus' poetic themes over her own, inasmuch as the shades judge : nec plus Alcaeus, consors patriaque lyraeque/ laudis habet, quamuis grandius ille sonet ('Nor is Alcaeus more praised, sharer of land and lyre, although he sounds off more grandly', ES 29-30) exhibits awareness of the themes of dura nauis/dura fugae mala, dura belli (Hor. Carm. 2. 13. 27-28), neatly encapsulated in the assessment of grandius. ${ }^{36}$ If Sappho is acknowledging this moment of literary praise found in Horace, and differentiating herself from Alcaeus in this same way, she can presumably further identify the audience who, according to Horace, appreciates Alcaeus more because of his grander material: the shades. This internal literary awareness of audience preferences can therefore be manipulated to intertextual advantage, when it comes to a figure she is textually related to: it seems that the Ovidian Orpheus is determined not to be an elegiac Sappho to the shades, but a crowd-pleasing lyricist. Orpheus' song to the shades operates under the auspices of nothing so much as a Horatian lyric logic: omnia debemur uobis, paulumque morati/ serius aut citius sedem properamus ad unam ('we owe everything to you, and despite small delays, sooner or later we shall all arrive in this self-same seat, together', Met. 10. 32-33) is a sentiment directly inspired by Horatian expression :

omnes eodem cogimur, omnium

uersatur urna serius ocius

sors exitura et nos in aeternum

exsilium impositura cumbae. (Carm. 2.3.25-28) 
We are all compelled to the same place,

the urn turns for each of us sooner or later

the lot of coming abandon, and we shall all weigh down

the skiff of forever exile.

Given Horace's poetic self-styling as a Roman Alcaeus, Ovid's use of Horace's words to illustrate the message of Orpheus' song to the shades in order to regain his wife can be construed as part of a complex self-conscious cycle of allusions: the shades prefer Alcaeus to Sappho, as demonstrated in Horace's poetic catabasis, and so Ovid's Orpheus paraphrases the 'Roman Alcaeus' in his persuasive efforts in the Underworld. However, the situational basis of knowledge that underpins this sly paraphrasing comes from a Horatian ode that relies heavily upon the textual scenery of Georgics $4,{ }^{37}$ so linking the two Orpheuses: Ovid's Orpheus, through a receptive Horatian filter, is made to functionally reprise the figure of the Virgilian Orpheus, in an act that represents a poetic strategy subtly advised by the Ovidian Sappho (who also textually relies upon the Virgilian Orpheus) through her acknowledgment of Alcaeus and his material. Virgil does not report Orpheus' song to the shades in the fourth Georgic, so the lyric momentum of the Ovidian Orpheus' song are part of a poetic design that purposefully differentiates the Ovidian presentation of the mythical bard, but yet makes him dependent upon his Virgilian construction. The grove of literary allusions that grow around the figure of Ovid's Orpheus begins and ends with Virgil, and throughout are predicated upon this associative poetics of umbra to create the intentional atmospheric ambiguity of what it means to sing to an audience of shades, and how to do it.

\section{Tree Catalogues and Funeral Pyres : Problematising the Orphic Locus Amoenus}

If Orpheus is reprising the environment of the Underworld in the creation of his grove, and reprising his original audience through the manipulation of umbra's double meaning, this makes any assessment of the space as a locus amoenus ultimately untenable. This argument has been extended for Orpheus' grove, in a discussion Hinds makes of the ecphrastic est locus formula. It is worth quoting in full here :

Ovid applies the same kind of interest in formular play to the particular distillation of local description which is (or, if you will, which becomes) the locus amoenus. Since Curtius a passage from Met. 10 has been a byword here. An est locus-type opening describes the landscape in which the Ur-poet Orpheus sits down, like a pastoral shepherd, to sing the songs of love and loss which will occupy the rest of Ovid's book. However, a crucial element is lacking to the standard setting: shade (88 umbra loco deerat). Orpheus' famous telekinetic powers put him in a unique position to address this problem. Using his lyre to summon to the spot a forest of twenty-seven species, meticulously catalogued by Ovid (Met. 10.90-106), he supplies the missing element, in effect adjusting the real world to fit the proprieties of the rhetorical one : 90 umbra loco uenit. The very amplitude of the grove thus summoned is itself part of the passage's rhetorical self-consciousness...Orpheus' fictive status as humankind's originary bard opens up a novel way of reading his virtuoso creation of shade at Met. 10.86-90: not as a belated play upon a well-established poetic topos or commonplace, but as an account of the first invention of the ideal landscape. ${ }^{38}$ 

lack of running water and light, refreshing breezes) to the original locus amoenus detracts from a different consideration of what the primary design of such a catalogue of trees is intended for: a new Underworld for Orpheus, and a transformation of an epic topos, for Ovid. The grove, as a doublet of the Underworld, is intrinsically inamoenus, in line with the kingdom of Hades being designated inamoena regna (10.15). ${ }^{39}$ The role of the grove as a neo-Underworld for Orpheus plays part of a wider narrative purpose for Ovid : to present the grove of Orpheus as a poetic, symbolic funeral pyre. for a funeral pyre; the list denotes those species felled for its creation. ${ }^{40}$ The appearance of the tree-felling topos can be traced back to the pyre made for Patroclus (Hom.Il. 23.117-20). Ennius 'translates' and modifies this passage to portray the preparations for burying the casualties of the battle of Heraclea in 280 B.C. (Ann. 6. fr. 175-179 Sk. = Macrob. Sat. 6. 2.27) :

incedunt arbusta per alta, securibus caedunt, percellunt magnas quercus, exciditur ilex, fraxinus frangitur atque abies consternitur alta, pinus proceras peruortunt : omne sonabat arbustum fremitu siluai frondosai.

They proceeded through the deep thicket, and struck with axes, they downed great oaks, the holm is hewn down, the ash is crashed down and the high fir felled, the stately pines upturned : the entire thicket of forest sounds forth in a leafy roar.

Ennius' version, as is clear, has expanded the type of trees from one to five (oak, holm oak, ash, fir, and pine), and rather than use compound adjectives as poetical adornment, he has personalised the felling of each tree with an individualised verb and a variety of sound effects created by alliteration and assonance. This act of personalising the experience creates a greater tone of emotional consequence, which invests the trees with an almost human presence and significance that is absent in their Homeric forebears, a conceit readily used by Ovid. Siluai here could also operate as a literary pun ; in Latin, silua comes to be used as a term signifying material for literary composition (OLD s.v. $5 b$ ), based on the double meaning of the Greek word or 'raw material', 'matter'). ${ }^{41}$ If this conceit is already in place by Ennius' time, the sense is that in this passage, the forest echoes with the sounds of Homer's literary material.

The metapoetic valence of silua is certainly in poetic currency when Virgil adapts the topos for the beginning of Aeneid 6, where the preparations for the pyre of Misenus are illustrated :

itur in antiquam siluam, stabula alta ferarum;

procumbunt piceae, sonat icta securibus ilex

fraxineaeque trabes cuneis et fissile robur

scinditur, aduoluunt ingentes montibus ornos. (Aen. 6.179-182)

An ancient wood is broached, the deep lair of beasts ;

the pines pitch forward, the axe-struck holm-oak sounds,

the beams of ash and splintery oak are cleaved with wedges

the huge rowans are rolled down from the mountains. 
31 phrase indicates either the Trojans making their way into an ancient wood, or, the poet proceeding into Ennius' older literary material. ${ }^{42}$ Once again, Virgil has varied the original oaks of Homer, leading the catalogue with spruce before moving on to holmoak, ash, oak, and mountain ash (or rowan). ${ }^{43}$

In later epic, Silius Italicus' Punica furnishes a tree catalogue ; the list of trees contains mountain ash (ornus), poplar (populus), holm-oak (ilex), oak (quercus), pine (pinus) and the cypress (cupressus, Pun. 10.527-535). The Thebaid provides another spectacular example at 6.90-107, in which Statius includes the beech (fagus), oaks (Chaoniumque nemus), cypress (cupressus), spruce (piceae), mountain ash (orni), holm-oak (iliceaeque trabes), the yew-tree (taxus), and more oak (robur), as well as fir (abies), pine (pinus), alder (alnus) and elm (ulmus). Statius' version (likely written before Silius Italicus') apart from his clear indebtedness to Virgil (procumbunt piceae, iliceaeque trabes, the use of scinditur with enjambment), also enjoys a small measure of engagement with the grove that Orpheus summons. ${ }^{44}$ And so, one might justifiably ask, given the traditional status of this poetic topos as an indelible part of the epic brand, why has the evercompetitive Ovid neglected this opportunity to insert his own version of the motif and sportingly vie with his poetic predecessors $?^{45}$ To just such a posed question, I would propose that the grove of Orpheus is intentionally designed to repurpose this customary use of tree catalogues. The felling is supplanted by the act of summoning, a different category of displacement via uprooting. Taken comprehensively, the creation of the grove functions on a symbolic level as the construction of a poetic funeral pyre, broadening the significance of the grove as a reconstructed Underworld. Ovid's repurposing of this epic tradition allows the customary situational frame to be evoked, yet not replicated. The tree catalogue is itself the product of literary metamorphosis. Styling the grove as the material for a poetic funeral pyre is also logically coherent within the narrative progression of the tale: it is while Orpheus is singing to this specially formed audience of trees that he attracts the attention of the Bacchic zealots who proceed to dismember him. The grove and the poetics of exclusion it engenders, made specifically for Orpheus by Orpheus, directly relates to (if not fully catalyses) the death of the poet.

\section{Conclusion}

Orpheus' grove represents a transformation across both levels of narrative, as Ovid transforms the topos of the epic tree catalogue and Orpheus transforms the Thracian landscape into his personal version of the Underworld. Orpheus creates this specialised atmosphere in which to sing his final song, a song that this very atmosphere is designed to assist, by looking back to his performance in the Underworld. Orpheus' loss is drawn against this background and audience of trees; he calls them together, in all their abundance, in an act of surrogacy for the shade that is lost to him while he yet lives-his wife Eurydice. Far from being the originary locus amoenus, the stand of trees summoned preserves Orpheus in a type of living death, while he relives his experiences of love and loss through the notes of his song. Understanding this landscape design, purposefully constructed to recreate the Underworld, rests fundamentally on the dual significance of umbra, a semantic overlap that carries with it the weight of inherited literary meaning and symbolism, yet here comes to a fruition that has wider, 
overarching interpretive ramifications for Metamorphoses 10 and Orpheus' role within it. Ovid gathers the legacy of ambiguity resultant from Virgil's collective, allusive engagement with umbra and its expressive potential, especially found in the myth of Orpheus from Georgics 4, to both characterise and situate his Orpheus, and encloses him within a landscape atmospherically delineated by this poetics of umbra. The grove of Orpheus is both formed from and casts the shade of literary influence, shadows Orpheus neither can nor wants to rise from, no matter how harmful.

\section{BIBLIOGRAPHY}

Barchiesi, A. (1993) ‘Future Reflexive : Two Modes of Allusion and Ovid's Heroides', HSCP 95 : 333-365

Barchiesi, A. and G. Rosati (eds.) (2007) Ovidio. Metamorfosi. vol. II (Libri III-IV). Milan

Bernstein, N. (2011) 'Locus Amoenus and Locus Horridus in Ovid's Metamorphoses', Wenshan

Review of Literature and Culture $5.1: 67-98$.

Bömer, F. (1969-1986) P. Ovidius Naso Metamorphosen : Kommentar. Heidelberg

Clausen, W.V. (1994) A Commentary on Virgil, Eclogues. Oxford

Fabre-Serris, J. (2005) 'Histoires d'inceste et de furor dans les Métamorphoses 9 et dans le chant en catalogue d'Orphée : une réponse d'Ovide au livre 4 des Géorgiques', Dictynna 2

Fernandelli, M. (2012) Via Latina : Studi su Virgilio e sulla sua fortuna [Polymnia 15]. Trieste

Galand-Hallyn, P. (1994) Le reflet des fleurs: Description et métalangage poétique d'Homère à la Renaissance. Geneva

Garrison, D. (1992) 'The "Locus Inamoenus" : Another Part of the Forest', Arion 2 : 98-114

Gowers, E. J. (2000) ‘Vegetable love : Virgil, Columella, and garden poetry’, Ramus 29 : 127-48

Groningen, B. A. van (1977) Euphorion. Amsterdam

Hallett, J. P. (2005) ‘Catullan Voices in Heroides 15 : How Sappho Became a Man', Dictynna 2

Hardie, P. R. (2002) Ovid's Poetics of Illusion. Cambridge

Harrison, S. J. (2013) 'Didactic and Lyric in Horace Odes 2 : Lucretius and Vergil', in T.D. Papanghelis, S.J. Harrison and S. Frangoulidis, eds. Generic Interfaces in Latin Literature : Encounters, Interactions, and Transformations. [Trends in Classics Supplementary Volume 20] :367-384. Berlin and Boston

Heurgon, J. (1931) ‘Un exemple peu connu de la retractatio virgilienne’, REL 9 : 258-268

Hinds, S. E. (1987) The Metamorphosis of Persephone: Ovid and the Self-Conscious Muse. Cambridge .(1998) Allusion and Intertext : Dynamics of Appropriation in Roman Poetry. Cambridge .(2002) 'Landscape with Figures : aesthetics of place in the Metamorphoses and its tradition', in P. Hardie, ed. The Cambridge Companion to Ovid : 122-149. Cambridge 
Houghton, L. B. T. (2007) 'Tibullus' Elegiac Underworld', CQ 57 : 153-165.

Jouteur, I. (2001) Jeux de genre dans les Métamorphoses d'Ovide. Leuven

Kennedy, D. F. (1983) ‘Shades of Meaning : Virgil, Eclogue 10.75-7', LCM 8.8 : 124.

Knox, P. E. (1995) Ovid: Heroides. Select Epistles. Oxford

Lacki, G. C. (2010) 'In the Darkness of Hell : Ovid Heroides 16. 211-12', CQ 60 : 661-663

Lamb, R. W. (1950) ‘Some Poetical Forests', G\&R 19 : 29-35

Leigh, M. (1999) 'Lucan's Caesar and the Sacred Grove : Deforestation and Enlightenment in Antiquity', in P. Esposito and L. Nicastri, eds. Interpretare Lucano : Miscellanea di Studi, 167-205. Naples ( = C. Tesoriero, ed. (2010) Oxford Readings in Lucan, 201-238. Oxford)

Maltby, R. (1991) A Lexicon of Ancient Latin Etymologies. Leeds

Mynors, R. A. B. (1990) Virgil's Georgics. Oxford

Nisbet, R. G. M. and Hubbard, M. (1978) A Commentary on Horace: Odes, Book 2. Oxford

Pardini, A. (1991) 'La ripartizione in libri dell'opera di Alceo : Per un riesame della questione’, RFIC 119 : 257-84

Pavlock. B. (2009) The Image of the Poet in Ovid's Metamorphoses. Madison

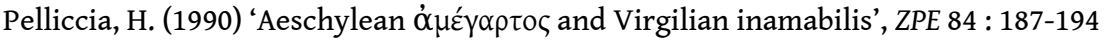

Porro, A. (1994) Vetera alcaica : L'esegesi di Alceo dagli Alessandrini all'età imperiale. Milan

Pöschl, V. (1960) ‘Der Katalog der Baume in Ovids Metamorphosen', in H. R. Jauss and D. Schaller, eds. Medium aevum vivum : Festschrift für Walter Bulst, 13-21 : Heidelberg

( = M. von Albrecht and E. Zinn, eds. (1968) Ovid, 393-404. Darmstadt)

Putnam, M. C. J. (1965) The Poetry of the Aeneid : Four Studies in Imaginative Unity and Design. Cambridge, Mass.

Reed, J. D. (ed.) (2013) Ovidio, Metamorfosi. Volume V (Libri X-XII). Milan.

Romeo, A. (2012) Orfeo in Ovidio : la creazione di un nuovo epos. Calabria

Rosati, G. (1996) 'Sabinus, the Heroides and the Poet-Nightingale. Some Observations on the Authenticity of the Epistula Sapphus', CQ 46.1 : 207-216

Schiesaro, A. (2006) 'A Dream Shattered ? Pastoral Anxieties in Senecan Drama', in M. Fantuzzi and T. Papanghelis, eds. Brill's Companion to Greek and Latin Pastoral : 427-449. Leiden

Smith, P. L. (1965) ، “Lentus in Umbra” : A Symbolic Pattern in Vergil's “Eclogues” ', Phoenix 19 : 298-304

Stephens, W. C. (1958) 'Descent to the Underworld in Ovid's Metamorphoses', CJ $53: 177-183$

Tarrant, R. J. (1980) 'The Authenticity of the Letter of Sappho to Phaon (Heroides XV)', HSCP 85 : $133-153$

Theodorakopoulos, E. (1997) 'Closure : the book of Virgil', in C. Martindale, ed. The Cambridge Companion to Virgil : 155-165. Cambridge

Williams, G.W. (1968) Tradition and Originality in Roman Poetry. Oxford

Wiseman, T. P. (1979) Clio's Cosmetics: Three Studies in Greco-Roman Literature. Leicester. ( = Gaisser, J. H., ed. (2007) Oxford Readings in Catullus : 66-74. Oxford) 
Woodman, A. J. (2012) ‘A covering letter : Poem 65’, in I. M. Du Quesnay and A. J. Woodman, eds. Catullus : Poems, Books, Readers : 130-152. Cambridge

\section{NOTES}

1. The exchange between the two figures is based upon a Virgilian understanding of umbra as pioneered by the Eclogues; this understanding is formulated in the opening line of Smith's (1965, 298) classic discussion of the bucolic topos, "The most prominent pattern of visual imagery in Vergil's Eclogues is that associated with ideas of shade and repose-umbra and otium." Cf. also how Venus settles herself and Adonis within a poplar shade to tell her own inset tale of Atalanta (Met. 10. 554-559).

2. A notable exception is Pöschl $(1960=1986)$, who attempts to assign generic meaning to the company of trees in identifying what he considers a transitional progression from epic to elegy and back to epic again throughout the catalogue. See also Galand-Hallyn (1994) 230-233 and Romeo (2012) 45-49. For a symbolic analysis of shade within the Metamorphoses, see Jouteur (2001) 239-242, esp. 239. She does not discuss the grove of Orpheus within this context, but sees the concept of shade in its use across the Metamorphoses as a dangerous presence, a conceptualisation that suffers slightly from its reductionist view of the ways in which Ovid draws upon a host of meanings and associations.

3. Before its dual appearance at 1.88 and 90 , umbra is also found in the opening of Book 10 at 1.12 , 16, and 48; altogether, it is found ten times in Book 10, whilst any other single book can only boast up to a maximum of six instances (as noted by Stephens [1958] 180). For the literary history and significance of umbra as meaning 'ghost,' see the commentary of Reed on the umbras of 1.48, p. 177.

4. See Bömer ad loc, who claims no connection exists.

5. Stephens $(1958,180)$ "Because Eurydice was not with Orpheus (umbra loco deerat), he was dispirited, but when he sings of love, her ghost appears (umbra loco uenit). We have a parallel to the visit to Hades; again Orpheus wins back his wife, although for a short time, by his art." Reed's note ad 90 is restricted to the following: "<ombra>, metonimia per gli alberi stessi, denota che Orfeo ha controllo su almeno un tipo di umbra: Stephens 1957 pp.22-23 sottolinea il parallelo con l'umbra di Euridice," citing the earlier dissertation that Stephens' 1958 publication comes from, but not elaborating in any substantial way.

6. Virg. Georg. 4. 481-484; Aen. 6. 547-627; Tib. 1.3. 67-82 (with the reading of Houghton [2007]); Prop. 2.1.65-68; 2.17.5-10

7. In similar fashion, see also the commentary of Reed ad 10.11-12 for the complexities of the oppositional construction there between umbrae and aurae.

8. As is the famed experience of not only Aeneas (Aen. 2.792-794 $=6.700-703$ ) but also the Orpheus of the Georgics (Georg. 4. 497-502) and Metamorphoses (Ov. Met. 10.58-59). Cf. also the commentary of Reed ad 10.11-12 for further complexities of the parallel constructions between umbrae and aurae.

9. Ovid's own cosmogony (both in the sense of the world and his epic) begins with Chaos, hearkening back to Hesiod (Theog. 116-117):

ante mare et terras et quod tegit omnia caelum

unus erat toto naturae uultus in orbe,

quem dixere Chaos. (Met. 1.5-7)

Before the sea and lands and everything the sky covered

there was one face of nature to the entire world,

which was known as Chaos. 
The heroic Orpheus was also known for singing a cosmogony (Ap. Rhod. Argon. 1.494-511). Maltby (1991) s.v. Chaonia only refers to the region's name as a derivation from the eponymous hero Chaon, but this does not wholly detract from the possibility that the poet is making suggestive wordplay between Chaos and Chaonia. One might further note that a different region in Epirus, Thesprotia, was said to contain an entrance to the Underworld, largely through affiliations with the Acheron; cf. Paus. 1.17.5, 9.30.6; Tzetz. ad Lycoph. 704; Plin. HN 4.2; Strab. 6.1.5; Thuc. 1.46.

10. See the commentary of Reed ad loc. for similar usages of Chaos.

11. Regarding this passage, as noted by Hardie (2002) 157. Cf. also Leigh (1999) 187 n. $77=(2010)$

$221 \mathrm{n} .77$ for testimony.

12. See n. 7 .

13. See the commentary of Barchiesi and Rosati ad loc.

14. Hardie (2002) 157. Hardie further notes Narcissus as akin to Tantalus in experiencing eternally deferred pleasure, never being able to attain the object of his desire; this makes his reading of umbra for unda interesting in light of the argument Lacki (2010) makes for the emendation of unda to umbra in the allusion to Tantalus at Heroides 16.211-212: nec proauo Stygia nostro captantur in umbra/ poma nec in mediis quaeritur umor aquis. Taken with the poma of the following line, Tantalus consequently in Lacki's words $(2010,662)$ "snatches at fruits in 'hellish darkness', but more specifically, 'in hellish shade', -- the shade, that is of an understood tree." Hardie's discussion of Narcissus and Tantalus furnishes supporting evidence for this proposed emendation, which further supports my own line of thinking about Ovid's self-conscious play with the dual meanings of umbra in the way his Orpheus recreates the atmosphere of the Underworld.

15. For Narcissus, cf. esp. Met. 3.448-450.

16. Orpheus' eventual permanent reunion with Eurydice in the Underworld, without any behavioural restriction, also draws him closer to the experience of Narcissus' love: both Orpheus and Narcissus, now shades, are still absorbed by love for a shade (Ov. Met. 11. 61-66).

17. The use of tendo and its compounds with bracchium is especially favoured by Ovid, who makes use of this phrasal combination more than any other author; cf. however the Virgilian instance of bracchia tendens to describe a tree whose crown extends to heavens, and its roots to Tartarus (Georg. 2.296).

18. This construction of a textual grove is extended further through the poetic debt of the Narcissus passage to Propertius 1.18, where the poet removes himself to a distant landscape that he uses as a reflective sounding board whilst he laments the circumstances of his love, on which see Pavlock (2009) 24-26.

19. Barring rare instances of natural disasters; cf. Met. 2.260-261 and Met. 5. 356-358; the latter is to a certain extent inspired by Hom. Il. 20.61-66. Cf. also the gloomy grove of Seneca's Oedipus, which also lies in darkness (lucis et Phoebi inscius, 545).

20. Ovid's grove also narratively blocks the Sun; Helios is replaced by Arethusa as the figure who tells Ceres of her daughter's fate.

21. The most famous and final line of Gallus' lament (omnia uincit Amor; et nos cedamus Amori, Ecl. 10. 69) also inspires Orpheus' statement of uicit Amor (Met. 10. 26); see the commentary of Reed ad loc.

22. With the repeated use of cresco in both Gallus' lament (10.54) and Virgil's assessment of his own love there is perhaps an internal resonance with Ecl. 2.67 (et sol crescentis decedens duplicat umbras, 'and the sun withdrawing doubles growing shadows') and the shadows Corydon notes at the end of his declaration of love; another usage of shade to indicate the day drawing to a close, and not necessarily a positive image.

23. See the reading of Kennedy (1983) 124; for the concept of shade meaning influence, including that of a literary sort, see OLD s.v. umbra $3 \mathrm{~d}$ and the examples cited therewith.

24. I owe this observation, with thanks, to one of the anonymous reviewers. 
25. The specification of the poplar tree (populea) as the site of her grief could also make further allusions to the two senses of shade, for Phaethon's sisters were transformed into poplars out of grief; the small inset narration of this event in the Aeneid makes this connection more explicit with the formulation populeas inter frondes umbramque sororum (Virg. Aen. 10. 190). For the connection between the two passages, and the wider resonances between the Cycnus passage and the lament of Orpheus, see Fernandelli (2012) 128-129. In in the grove of Orpheus, the sisters of Phaethon are not specifically designated as poplars, but are simply designated by the phrase nemus Heliadum. Such a generalised designation is consistent with the picture of their metamorphosis in Book 2 (346-366), where the trees they become are not explicitly named. Elsewhere they become alders, as at Eclogue 6.62-63; cf. Clausen (1994) ad loc. Poplars are also associated with the Underworld through the figure of Hercules, who fashioned a wreath of white poplar to mark his ascent from the Underworld; For the associations between Hercules and the white poplar, see Paus. 5.14.2; Her. 9.64; Virg. Georg. 2.66 with Mynors (1990) ad loc., and Hor. Carm. 1.7.23, with Nisbet and Hubbard (1970) ad loc.

Servius ( $\mathrm{ad} E c \mathrm{cl}$. 7.61) also notes that the bicoloured leaves of the poplar symbolise the meeting of the upper and lower worlds, as the tree was created by Pluto to memorialise his love for Leuce.

26. This refashioning is well discussed by Putnam (1965) 41-47; cf. also Heurgon (1931).

27. Quaerenti (Aen. 2. 771) also in some ways textually echoes the queritur and questibus of the Georgics passage.

28. Gowers (2000) 132. Cf. also Theodorakopoulos (1997) 162-164.

29. Cf. Nisbet and Hubbard (1978) 201, 204-205 and esp. ad 2.13.33 and 36. For Horace's interest in the Virgilian Orpheus' descent to the Underworld as demonstrated in Odes 2, where recollections of this section of Georgics 4 appear in four different places, see Harrison (2013) 381-383.

30. The authenticity of the letter from Sappho to Phaon is heavily contested, but even if not by Ovid himself is composed in an indisputably Ovidian fashion. See Knox (1995) 12-14, who prints it under the heading of 'Incerti Auctoris', and the argument of Tarrant (1981), who reviews the scholarly argumentation around this question of authorship in outlining his own view of the letter as a non-Ovidian composition.

31. See Hallett (2005) for Catullus' presence within the epistle; for the importance of the nightingale and its connection to Catullus see Rosati (1996) 213-215. Given the two occurrences in Catullus and an epistle written by "Sappho," Woodman (2012) 142-143 postulates a Sapphic usage as the source for the derivations seen in Ovid and Catullus; the use of Daulias therefore allows Catullus to cast himself as both Sappho and Penelope, through the Homeric reminiscence of the myth; for a similar conclusion cf. Knox (1995) ad loc. For Catullus 65, elegy, and the Virgilian Orpheus see Barchiesi (1993) 363-365.

32. With attentiveness to names, it is also Catullus' use of Ityli that further flags intentional

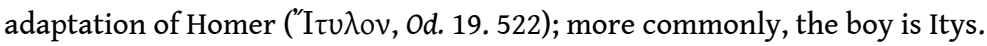

33. As observed by Woodman (2012) 141-142, who further notes the clever etymological gloss of Daulias provided by densis, given the meaning of the Greek adjective $\delta \alpha u \lambda$ ó as 'thick.' Orpheus' lament in the Georgics also looks back upon this passage, but, as Fernandelli $(2012,126)$ notes, "in realtà, mentre la presenza di Od. XIX 518-523, nel testo di Virgilio, si risolve nel singolo, convenzionale dettaglio dell'usignolo che canta sotto le fronde, la similitudine di Od. XVI 216-219 offre al poeta romano spunti ben più significativi," and identifies further important textual affiliations between this other Odyssean simile and the Virgilian text, a strategic decision of Virgil that lends further significance to Orpheus' lament through a privileging of a passage that represents "la soluzione meno ovvia" (128).

34. Wiseman (1979) $176=(2006) 67$.

35. The nightingale and its lament also mark a difference between the accounts of Persephone's rape in the Metamorphoses and the Fasti, as Ceres in the Fasti also mourns in the fashion of the Virgilian Orpheus: quacumque ingreditur, miseris loca cuncta querellis/ implet, ut amissum cum gemit 
ales Ityn (Fast. 4.481-482); cf. Hinds (1987) 104 and 160 n. 19 for its significance in signifying the Fasti's elegiac nature. The nightingale often seems to perch on poetic boundaries of particular generic significance: of further consideration is Callimachus' epigram in elegiac couplets for Heraclitus (Ep. 2 Pf. = $34 \mathrm{GP}$ ) which talks about his songs as nightingales; a persistent interpretive suggestion is that he was the composer of collection of elegiacs called 'Nightingales.' Again, in Callimachus' fifth Hymn, the only hymn written in elegiacs, Chariclo mourns for Tiresias like the nightingale (Callim. Hymn 5.93-95).

36. Alcaeus' work itself was also divided thematically by editors into political and non-political

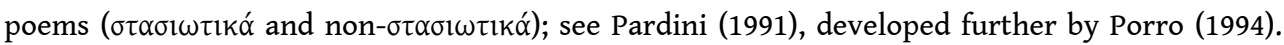
Knox (1995) ad ES 30 also identifies a link between this passage and the Horatian text.

37. A passage itself identified as lyric; cf. the discussion of Fernandelli (2012) 124-132 for the lyricism of the Orpheus-epyllion. For Orpheus within the lyric tradition, see the sources collected in Reed (2013) 165.

38. Hinds (2002) 127. See also Schiesaro $(2006,436)$, who says "In Book 10 of the Metamorphoses Orpheus literally 'invents' the idyllic landscape of the locus amoenus," as well as the description of Galand-Hallyn (1994, 230), "Le poète y décrit cette fois la création d'un locus amoenus par le plus prestigieux et le plus symbolique des poètes..." Bernstein (2011) 75-77 likewise describes it as a locus amoenus. Related to this idea of the locus amoenus, a few scholars have advanced the notion that the grove of Orpheus is connected to or reminiscent in some way of the Grynean Grove. Given the paucity of textual evidence available, it is difficult to assess how much merit this argument has, but it would seem to me to be a more secure connection to make only if Orpheus' grove were existing as a more straightforward example of a locus amoenus, given Servius' assessment of the grove as ubi est locus arboribus multis iucundus, gramine floribusque uariis omni tempore uestitus, abundans etiam fontibus (ad Ecl. 6.72). For these views, see Fabre-Serris (2005) 10-11 and Jouteur (2001) 70. For evidence of the Grynean Grove see van Groningen (1977) 169-170, ad Euphorion fr. 101. Of course, any possible evocation of the Grynean Grove does not necessarily diminish the ways in which Ovid is creating the space of Orpheus' grove as one of profound ambiguity, but to use this connection as a way to further entrench understanding of the grove as a locus amoenus seems misguided, given the complexity of its construction. Determining a literary category other than locus amoenus or locus horridus that is accommodating of this type of studied ambiguity is an a topic for an independent piece; presently, I will restrict remarks on this issue to state that for other literary groves that seem to have inherited the textual spirit of the Ovidian grove (as being neither straightforwardly amoenus, nor horridus) one might look to the grove of the Culex (109-145) and (as an anonymous reader has suggested, to which I am indebted), the 'shadie grove' of Spenser's Faerie Queen (I. i. 7ff.). Both groves are inclusive of an Ovidian-style tree catalogue, and incorporate notions of both sweetness and delight, and suggestive hints of the Underworld.

39. See the commentary of Reed ad loc. As Garrison (1992) 100 suggests, it is Ovid whose revision of the locus amoenus paves the way for the Silver Age commonality of the inamoenus; Ovid's use of the adjective at Met. 10.15 is its first recorded appearance and is readily appropriated by Silver Age poets (cf. Garrison n. 7). The Ovidian inamoena seems to be in dialogue with the Virgilian inamabilis of both Georg. 4.479 and Aen. 6.438 (especially given the use of inamabile regnum at Met. 4.477 and 14.590 , varying the inamoena regna of 10.15 . with the Virgilian adjective). Because it is tied to unda in both places within the Virgilian corpus, it would seem inappropriate for the strength of inamabilis to further cast over the grove that Orpheus creates, given its lack of running water; for analysis of the Virgilian use of inamabilis, and its affiliation with water, see Pelliccia (1990); cf. however the Ovidan usage at Tr. 5.7.43. Ovid's use of inamoena for the Underworld also sets it apart from Virgil's, for Anchises describes the place he inhabits in the Underworld as amoena at Aen. 5.734. Anchises' words are corroborated in Book 6 after Aeneas crosses into Elysium, deuenere locos laetos et amoena uirecta/ fortunatorum nemorum sedesque beatas 
('they came to the joyful places and greening pleasantries, and the blessed seats of blessed groves', Aen. 6.638-639), where he sees none other than Orpheus (Threicius...sacerdos, 6.645). Ovid is careful to differentiate his account of the Underworld, a difference that is acknowledged when Orpheus is reunited with Eurydice: Orpheus sees the places he saw before (et quae loca uiderat ante 11.61 ) but it is presumably in Elysium that he finds her (quaerensque per arua piorum/ inuenit Eurydicen, 11.62-63), a place reminiscent of Anchises' amoena piorum. This textual connection adds further meaning to Orpheus' suppression of any place of delight that he encounters on his tour of the Underworld in Book 10, which is further necessary if one consequently views the grove as a replication of the Underworld. Only when he regains Eurydice as a shade himself can places that are considered amoena exist for him.

40. Williams (1968) 263-267 uses this very phenomenon as an extended exemplum for his chapter on 'The Blending of Greek and Roman', tracing the poetic conceit from Homer to Statius, summarising grandly, "To some extent the history of Roman poetry is epitomized in the confrontation of these four passages from Ennius, Virgil, Silius, and Statius, if this is taken together with their relationship to the Greek of Homer." (267). Introducing the tree catalogue in his commentary, Reed notes this topos together with citing other examples of loci amoeni (185); he too uses this designation unproblematically to describe Orpheus' grove.

41. For this concept cf. Galand-Hallyn (1994) 120-121.

42. Hinds (1998) 11-14.

43. For a full analysis of the passage, see Williams (1968) 264 and Lamb (1950) 31.

44. Apart from the shared use of Chaonis to describe the oak, Statius' grove seems to nod toward the completeness of Ovid's with the descriptive phrase largae qua non opulentior umbrae/Argolicos inter saltusque educta Lycaeos/ extulerat super astra caput (Stat. Theb. 6.91-93); the specific detail of extulerat super astra caput is perhaps a reference to the tree that ends the Ovidian catalogue, the cypress, illustrated by sidereum gracili spectare cacumine caelum (Met. 10.140).

45. The only act of tree-felling for a funeral pyre occurs in Book 9, when Hercules, in the throes of suffering, prepares his own pyre (Met. 9.229-232). On a related note, it is useful to consider the felling of Hercules' funeral pyre as described in the Hercules Oetaeus, which provides another instance of the tree catalogue, albeit not in epic, but nevertheless in the 'higher' genre of tragedy. It begins with the felling of a beech and a pine that is reminiscent of the Homerically inspired formula for the felling topos, ending with the depiction of the sound, before breaking off and describing a huge oak, the felling of which comprises almost the rest of the passage: Chaonis quondam loquax /stat uasta late quercus et Phoebum uetat/ultraque totos porrigit ramos nemus ([Sen.] Herc. Oet. 1623-1625). Like the Ovidian groves we have seen, this oak is responsible for blocking out the sun. When the oak has finally been levelled, the sun's rays are admitted and the hitherto unseen flock of birds is dislodged and made to seek their nests: protinus radios locus/admisit omnis: sedibus pulsae suis/uolucres pererrant nemore succiso diem/quaeruntque lassis garrulae pinnis domus. ([Sen.] Herc. Oet. 1630-1633). The destruction of this oak and its forest for the funeral pyre of Hercules (the only pyre whose felling Ovid illustrates in the Metamorphoses) therefore seems a deconstruction or a dismantling of the atmospheric Underworld created by Orpheus' grove-the infernal elements are dispersed with the oak's felling. In the obverse way that the grove indicates a sort of living death for Orpheus, the return of sun and birds with the felling of the oak for the pyre indicates the final realm of Hercules will not be the Underworld. The two passages therefore seem related in their functions; and consequently, through such an act of reception on Seneca's behalf, lend credence to visualising the grove of Orpheus as a sort of poetic funeral pyre. Cf. Leigh (1999) $194-199=(2010) 228-232$ for the challenges against the darkness of the grove in the Hercules Oetaeus. 


\section{ABSTRACTS}

This paper reexamines the grove of Orpheus in Ovid, Metamorphoses 10, arguing that it is a space of complex ambiguity as activated and determined by the dual meaning of umbra. It conceptualizes the space as an atmospheric doublet of the Underworld, designed to give Orpheus imaginative access to his lost wife Eurydice by providing a second set of shade(s) as an audience for his song. By calling attention to the ways in which Orpheus' summoning of the grove casts it as a neo-Underworld, this paper seeks to unsettle the grove's persistent designation as the originary locus amoenus. Altogether, across the levels of narrative, Orpheus and Ovid engage in a receptive repurposing and manipulation of both the idea of literary shade (as inherited and adapted from Virgil) and the trope of the tree catalogue (as familiarised in epic) to create a landscape of profound liminality.

\section{INDEX}

Keywords: Ovid, Metamorphoses, Orpheus, grove, umbra, shade, locus amoenus, intertextuality, underworld 